\title{
GPS1 wt Allele
}

National Cancer Institute

\section{Source}

National Cancer Institute. GPS1 wt Allele. NCI Thesaurus. Code C52635.

Human GPS1 wild-type allele is located in the vicinity of $17 \mathrm{q} 25.3$ and is approximately $6 \mathrm{~kb}$ in length. This allele, which encodes COP9 signalosome complex subunit 1 protein, is involved in the modulation of both G-protein coupled receptor and mitogen-activated kinase signaling cascades. 